\title{
Preparation and Constitution of the Crystalline Silicic Acid Trimethylsilyl Ester $\left[\left(\mathrm{CH}_{3}\right)_{3} \mathrm{Si}_{6} \mathrm{Si}_{6} \mathrm{O}_{15}\right.$
}

\author{
D. Hoebbel ${ }^{* a}$ ), G. Engelhardt, A. Samoson ${ }^{b}$ ), K. Ujszászy ${ }^{c}$ ), and \\ YU. I. SMOLIN ${ }^{\text {) }}$ \\ Berlin-Adlershof ${ }^{\mathrm{a}}$ ), Centralinstitute for Inorganic Chemistry, Academy of Sciences of the G.D.R. \\ Tallin $n^{b}$ ) (U.S.S.R.), Institute for Chemical Physics and Biophysics, Academy of Sciences of the \\ Estonian S.S.R. \\ Budapest ${ }^{\mathrm{c}}$ ) (Hungary), Centralinstitute for Chemistry, Hungarian Academy of Sciences \\ Leningrad ${ }^{\mathrm{d}}$ ) (U.S.S.R.), Institute for Silicate Chemistry, Academy of Sciences of the U.S.S.R.
}

Abstract. A new crystalline compound has been synthesized by trimethylsilylation of tetra ethylammonium silicate which was identified by means of gas chromatography, mass spectrometry, ${ }^{29} \mathrm{Si} \mathrm{NMR}$ and X-ray analysis to be a cage-like double three-ring silicic acid trimethylsilyl ester containing six inequivalent $\mathrm{SiO}_{4}$ tetrahedra and trimethylsilyl groups.

\section{Herstellung und Konstitution des kristallinen Kieselsäuretrimethylsilylesters $\left[\left(\mathrm{CH}_{3}\right)_{3} \mathrm{Si}_{6} \mathrm{Si}_{6} \mathrm{O}_{15}\right.$}

Inhaltsübersicht. Durch Trimethylsilylierung des Tetraethylammoniumsilicats wurde ein neuer kristalliner Kieselsäuretrimethylsilylester hergestellt. Konstitutionsuntersuchungen mit Hilfe der Gaschromatographie, Massenspektrometrie, ${ }^{29}$ Si NMR- und Röntgenanalyse zeigen, da $\beta$ der Kieselsäuretrimethylsilylester aus käfigartigen Doppeldreiringen aufgebaut ist, die jeweils sechs nichtäquivalente $\mathrm{SiO}_{4}$ Tetraeder und Trimethylsilylgruppen enthalten.

\section{Introduction}

The double three-ring silicate anion $\mathrm{Si}_{6} \mathrm{O}_{15}{ }^{6-}$ in known as building unit of the crystalline silicate $\left[\mathrm{Ni}(\mathrm{en})_{3}\right]_{3} \mathrm{Si}_{6} \mathrm{O}_{15} \cdot 26 \mathrm{H}_{2} \mathrm{O}[1]$ and $\left[\mathrm{N}\left(\mathrm{C}_{2} \mathrm{H}_{5}\right)_{4}\right]_{6} \mathrm{Si}_{6} \mathrm{O}_{15} \cdot 57 \mathrm{H}_{2} \mathrm{O}$ [2], and has also been proved to be present in tetraethylammonium silicate solutions $[3,4]$. The trimethylsilyl ester of the double three-ring silicate $\left[\left(\mathrm{CH}_{3}\right)_{5} \mathrm{Si}_{6} \mathrm{Si}_{6} \mathrm{O}_{15}\right.$ $\left.\left(Q_{6} \mathrm{M}_{6}\right)^{1}\right)$ has been synthesized so far only in diluted solutions of organic solvents by trimethylsilylation of the above silicates or silicates solutions [3, 4]. However, difficulties arose in the preparation of the crystalline ester due to the high instability of the strained SiOSi bonds of the double three-ring structure against proton

\footnotetext{
1) In this article the following abbreviations are used: $\mathrm{Q}: \mathrm{Si}\left(\mathrm{O}_{0,5}\right)_{4} ; \mathrm{M}:\left(\mathrm{CH}_{3}\right)_{3} \mathrm{SiO}_{0,5}$
} 
attack [5]. We describe here for the first time the preparation of the pure crystalline $\mathbf{Q}_{6} \mathbf{M}_{6}$ compound and its structural characterization by gas chromatography, mass spectrometry, X-ray analysis, and solution and solid state ${ }^{29} \mathrm{Si}$ NMR.

\section{Preparation}

$\mathrm{Q}_{6} \mathrm{M}_{6}$ was synthesized by trimethylsilylation of tetraethylammonium silicate $\left[\mathrm{N}\left(\mathrm{C}_{2} \mathrm{H}_{5}\right)_{4}\right]_{6} \mathrm{Si}_{6} \mathrm{O}_{15} \cdot 57 \mathrm{H}_{2} \mathrm{O}$ according to the slightly modified method of TAMÁS et al. [6] but without treating the reaction product with cation exchanger.

A solution of $30 \mathrm{ml}$ trimethylchlorosilane, $30 \mathrm{ml}$ hexamethyldisiloxane, and $60 \mathrm{ml}$ dimethylformamide was vigorously stirred for $15 \mathrm{~min}$, and $1.4 \mathrm{~g}$ of the powdered silicate were added in small portions at $15^{\circ} \mathrm{C}$. The mixture was stirred for another $15 \mathrm{~min}$ and $100 \mathrm{ml}$ of water cooled to $2{ }^{\circ} \mathrm{C}$ were added. Subsequently, the organic phase was separated and washed with water until neutral reaction was achieved. After partial removal of hexamethyldisiloxane under vacuum at $35^{\circ} \mathrm{C}$ a portion of $0.58 \mathrm{~g}$ (yield: $61 \%$ ) colorless crystals were obtained from the residual liquid phase.

Elemental analysis of the crystals gave carbon and hydrogen contents of $25.6 \%$ and $6.5 \%$, respectively (calculated for $\mathrm{Q}_{6} \mathrm{M}_{6} 25.5 \% \mathrm{C}$ and $6.4 \% \mathrm{H}$ ). The capillary gas chromatogram of the erystals solved in heptane shows a single peak in the retention region typical for compounds of six M groups [3].

\section{Structure Characterization}

The molecular mass of the silicic acid trimethylsilyl ester was determined by mass spectrometry. In the mass spectrum the $\mathrm{M}-\mathrm{CH}_{3}$ peak, characteristic of methylsiloxanes, was observed at $\mathrm{m} / \mathrm{z} 831$. This indicates a molecular mass of 846 for the crystals. Elemental composition of the $\mathrm{m} / \mathrm{z} 831$ ion, determined from exact mass measurements is $\mathrm{Si}_{12} \mathrm{O}_{15} \mathrm{C}_{17} \mathrm{H}_{51}$ (831.0441 measured, 831.0459 calculated) in accordance with' the expected $Q_{6} M_{6}$ structure. The MS fragmentation pattern of $Q_{6} \mathbf{M}_{6}$ shows no significant differences to that of the larger cage-like silicic acid trimethylsilyl esters $\mathbf{Q}_{8} \mathbf{M}_{8}$ and $\mathbf{Q}_{10} \mathbf{M}_{10}$.

The ${ }^{29} \mathrm{Si}$ NMR spectrum of $\mathbf{Q}_{6} \mathrm{M}_{6}$ in heptane solution displays two sharp peaks at $+13.5 \mathrm{ppm}$ and $-98.8 \mathrm{ppm}$ für the $\mathrm{M}$ - and Q-type silicons, respectively (see Fig. 1a). This indicates a highly symmetrical structure of the $Q_{6} M_{6}$ molecule with equivalent silicons in either of the six $Q$ and $M$ sites or a fast dynamic exchange between inequivalent sites. As expected for the trimeric ring, the peak of the $Q$ silicons is strongly shifted to low field in comparison to the double four- and double five-ring compounds $\mathbf{Q}_{8} \mathbf{M}_{8}(-108.3 \mathrm{ppm})$ and $\mathbf{Q}_{10} \mathbf{M}_{10}(-109.7 \mathrm{ppm})$ [7] Corresponding low-field shifts of the double three-ring silicate anions have been observed in tetraethylammonium silicate solutions [3].

In contrast to the solution spectrum of $\mathrm{Q}_{6} \mathrm{M}_{6}$, the high-resolution ${ }^{29} \mathrm{Si} \mathrm{NMR}$ spectrum of solid $\mathbf{Q}_{6} \mathbf{M}_{6}$ shows splittings into several lines both for the $M$ and $\mathbf{Q}$ peaks. The solid-state ${ }^{29} \mathrm{Si}$ NMR spectrum is shown in Fig. $1 \mathrm{~b}$ and the splitting of the $M$ peak into six lines and the $Q$ peak into five lines with one having double intensity is clearly visible. The solid-state spectrum reveals that the six silicons in either of the $\mathbf{Q}$ and $M$ sites of the $Q_{B} M_{6}$ structures are no longer equivalent in the crystalline solid but characterized by slightly different bonding geometry. From 


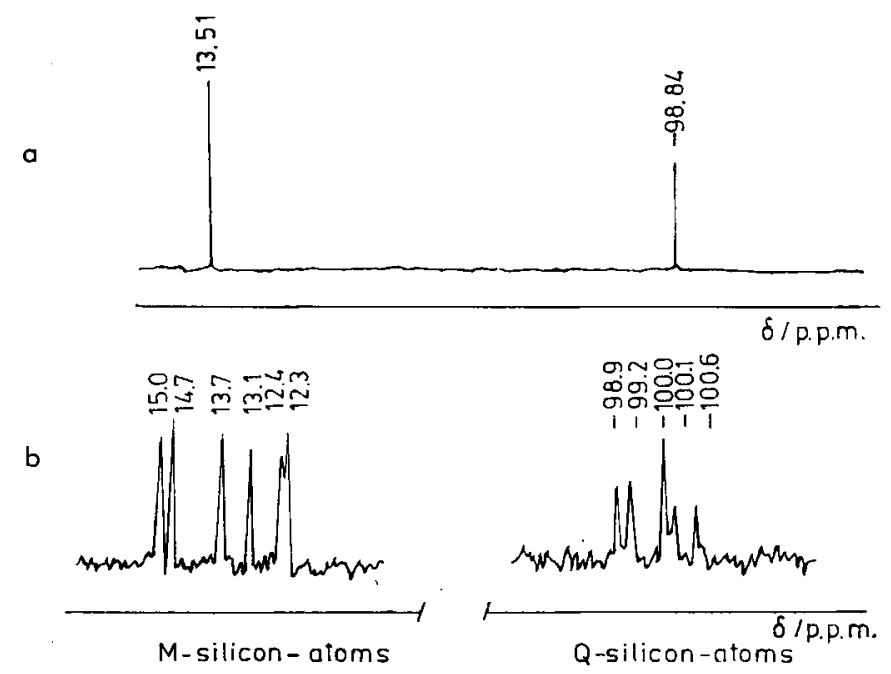

Fig. $1{ }^{29} \mathrm{Si}$ NMR spectra of $\mathrm{Q}_{6} \mathrm{M}_{6}$ in heptane solution (a) and in crystalline state (b).

$X$-ray diffraction of $\mathrm{Q}_{6} \mathrm{M}_{6}$ follows the space group $\mathrm{P} 2_{1} / c$ with four equivalent molecules in the unit cell. The parameters of the unit cell are $\mathrm{a}=2.1386(3)$, $\mathrm{b}=2.3510(3), \quad \mathbf{c}=1.0959(2) \mathrm{nm}$ and $\beta=119.75(5)^{\circ}$. The structure analysis (1700 reflections, final $R=0.07$ ) shows that in the crystalline state the $\mathbf{Q}_{6} \mathrm{M}_{6}$ molecule is asymmetrically distorted which confirms the conclusions derived from the solid-state ${ }^{29} \mathrm{Si}$ NMR spectrum. In Fig. 2 the structure of the $\left[\left(\mathrm{CH}_{3}\right)_{3} \mathrm{Si}_{6} \mathrm{Si}_{6} \mathrm{O}_{15}\right.$ molecule is given. The atoms are depicted as $50 \%$ probability thermal ellipsoids, the hydrogens have been omitted. From Fig. 2 follows that the central part of the molecule is built up of a cagelike double ring of six $\mathrm{SiO}_{4}$ tetrahedra, each of them connected to three neighbouring $\mathrm{SiO}_{4}$ tetrahedra by sharing oxygen atoms. The fourth oxygen atom of the $\mathrm{SiO}_{4}$ tetrahedra is linked to the $\left(\mathrm{CH}_{3}\right)_{3} \mathrm{Si}$ group. All bond length within the molecule are different. The $\mathrm{Si}-\mathrm{O}$ bond length are $0.156(1)-0.163(1) \mathrm{nm}$ and the $\mathrm{Si}-\mathrm{C}$ distances, under consideration of the thermal motion, are $0.170(4)-0.189(3) \mathrm{nm}$. A detailed description of the $\mathrm{Q}_{6} \mathrm{M}_{6}$ structure will be published elsewhere [8].

The results of this study reveal unambiguously that the double three-ring structure of the crystalline $Q_{6} M_{6}$ is asymmetrically distorted in a similar way as observed for the solid double four-ring and double five-ring silicic acid trimethylsilyl ester $\mathbf{Q}_{8} \mathbf{M}_{8}[9,10]$ and $\mathbf{Q}_{1,0} \mathbf{M}_{10}[9]$, respectively.

\section{Experimental}

${ }^{29} \mathrm{Si}$ NMR. The ${ }^{29} \mathrm{Si}$ NMR spectrum of $\mathrm{Q}_{6} \mathrm{M}_{6}$ in heptane solution was measured with a NMR spectrometer Jeol PS 100 at $19.87 \mathrm{MHz}$, pulse repetition $60 \mathrm{~s}$, flip angle $60^{\circ}$, number of scans: 36 . The solid-state ${ }^{29} \mathrm{Si}$ NMR spectrum were measured on a Bruker CXP 200 instrument at $39.74 \mathrm{MHz}$ 




Fig. 2 Structure of the $\left[\left(\mathrm{CH}_{3}\right)_{3} \mathrm{Si}\right]_{6} \mathrm{Si}_{6} \mathrm{O}_{15}$ molecule. For details see [8].

using CP-MAS technique with $60 \mathrm{~s}$ pulse repetition, $5 \mathrm{~ms}$ contact time, ans $3 \mathrm{KHz}$ rotation frequency. Number of scans: 27.

Mass spectrometric measurements were performed on a AEI MS 902 instrument at $70 \mathrm{eV}$ ionizing energy. The temperature of the ion source was $180^{\circ} \mathrm{C}$. The sample was introduced directly into the ion source from a quartz probe.

The authors thank Dr. D. Müller, D. Heidemans, and T. Reiher for carrying out of experiments and helpful discussions.

\section{R9le:ances}

[1] Smours, Yu. I.: Kristallografiya 15 (1970) 31.

[2] Smolin, Yu. T.; Shepelev, Yu. F.; Ershov, A.S.; Hoerbèl, D.; Wreker, W.: Kristallografiya 29 (1984) 712.

[3] Hoebbel, D.; Garzó, G.; Engelhardt, G.; Ebert, R.; LiprmaA, E. ; Alla, M.: Z. anorg. allg. Chem. 465 (1980) 15.

[4] Hokbbel, D.; Vargha, A.; Farlke, B.; Engelhardt, G. : Z. anorg. allg. Chem. 521 (1985) 61. 
[5] Garzó, G.; Hoebbri, D.; Vargha, A.; Ússzászy, K.: J. Chem. Soe., Dalton Trans. 1984, 1857.

[6] Tamás, F. D.; Sarkar, A. K.; Roy, D. M.: Hung. J. Ind. Chem. 5 (1977) 115.

[7] Hofbbel, D.; Garzó, G.; Engelhardt, G.; Janche, H.; Franke, P.; Wieker, W.: Z. anorg. allg. Chem. 424 (1976) 115.

[8] Shepelev, Yu. F.; Smolıi, Yu. I.; Eršov, A. S.; Hoebbet, D. : Kristallografiya in press.

[9] Engelhardt, G.; Zeigan, D.; Hoebbel, D.; Samoson, A.; LippmaA, F.: Z. Chem. 22 (1982) 314.

[10] Smolin, Yu. I.; Shepelev, Yu. F.; Pomes, R.: Khimija Silikatov i Oksidov, Leningrad: Nauka 198:, S. 68.

Bei der Redaktion eingegangen am 22. Januar 1987.

Anschr, d. Verf,: Dr. D. Hoesbel, Zentralinst. f. Anorg. Chemie der AdW der DDR, Rudower Chaussee 5, Berlin-Adlershof, DDR-1199 